\title{
Anagrams etc. The interpretive Dilemmas of Lady Eleanor Douglas
}

RICHARD

PICKARD

Summary: The period 1620-1660 saw the emergence of several English women, of varying classes, who chose Biblical prophecy as an entry into public, political discourse. Many of these women, such as Hester Biddle and Margaret Fell Fox, stated their opinions with relative clarity. Lady Eleanor Douglas, however, made a career of powerfully impenetrable, allusion-filled writing. This paper proposes some methods of addressing Douglas's texts, and works through some particularly difficult passages.

And shunning Circumlocution, where like theirs under terms Enigmatical, concealed by way of Numbers and Figures numberless. Whosoever understands any one, serves for the master Key to that Hidden Treasure or Quintesence.

Lady Eleanor Douglas. The Restitution of Prophecy, 44.

$\mathrm{T}$ he only thing certain about the writings of Lady Eleanor Douglas is their radically destabilizing effect on the reader. Douglas's massive disruptions of syntax, of grammar, of allegorical reference deny her reader even the most primal access to the textual space in which she locates herself and to the phenomenal space in which she locates her texts. Her world is fundamentally textual, open to redefinition through the interpretive act embodied by her entry into textuality. Because of this radical instability of both sign and referent, Douglas's pamphlets have been denigrated as the result of madness aggravated by inadequate education. However, as Megan Matchinske proposes, Doug- 
las's rhetoric "suggest[s] writing techniques that privilege Davies's secrets and demand their attention and discovery by observant readers." 1 The phrase "observant readers," although accurate, conceals the level of complexity achieved by Douglas. Her secretive rhetoric succeeds so well as to create and demand interpretive pressures extreme enough to destroy the stability of the text, of language, of meaning itself.

Born in about 1590, the fifth daughter of George Touchet, Baron Audley and Earl of Castlehaven, Lady Eleanor's upper-class status was solidified by her marriages to Sir John Davies and Sir Archibald Douglas. The most significant moment of her life occured in 1625, when she found herself called - literally awakened by an unseen voice in her bedroom, in most of her narratives of the incident - to prophesy the Judgement to come in nineteen and one-half years. She felt her prophetic calling confirmed when she realized that her maiden name, Eleanor Audley (if spelled "Audelie"), formed the singularly prophetic anagram "Reveale O Daniel" (with the permissible typographical shift of "u" to "v"). Douglas's great problem. as a prophetess supported neither by those in power nor by religious sympathizers (such as the Society of Friends), and probably reduced to having her texts printed at her own expense, was in finding recognition. In a startling piece of understatement, Esther Cope comments that "Lady Eleanor did not win the tolerance that divine inspiration often provided for prophets." 2 Imprisoned at least four times, and committed to Bedlam for 16 months, Douglas found almost constant persecution that only lifted, and then only briefly, in the political confusion of the 1640s. Readership of the tracts which she published throughout the rest of her life is impossible to decide, but it is clear that her more specific prophecies were fairly common knowledge. As early as June 1628, she had prophesied that the Duke of Buckingham would die in August, according to a letter by Dr. Mead from Christ's College, Cambridge ${ }^{3}$ her reputation was confirmed by Buckingham's stabbing death on August 23, but this did not smooth the reception of her writings then, and has not done so now.

Postmodern criticism tends to rehabilitate and privilege writers and texts whose style presses against and unsettles the structures of language: criticism for this reason recognizes Joyce and Stein to be as much postmodern as modernist, Laurence Sterne's Tristram Shandy to be a celebrated precursor of postmodernism, Gabriel García Márquez's Autumn of the Patriarch to be indispensable for an understanding of magic realism. The principle of jouissance, of linguistic play, is evoked to signify the writer's recognition of language as an arbitrary code whose cryptic nature only escapes notice because of society's 
broad indoctrination into it. Linguistic play not only excuses deliberate obscurity, but celebrates it; Eleanor Douglas, like Stein and García Márquez, seems tailor-made for postmodern criticism. ${ }^{4}$ However, in spite of her stylistic similarities to favoured postmodern texts, Douglas has attracted little critical attention, and precious little of that being positive.

Her own version of linguistic play derives from her place in the seventeenth century, "a culture already caught up with anagrams and Biblical exegesis." In several of her texts, Douglas quite explicitly refuses to write clearly or simply; the preface to The Lady Eleanor, Her Appeale to the High Court of Parliament describes itself as necessary, but not conventional:

The roade way not to baulke, a preface omitted neither to the reader: complement, although layd aside, soft lineing of that sort, these therwith prefaced not; rather preferred for all weather serviceable, a peece of plaine Leather . . .; this peece or apollogie serving, set here without coulours or flowers, as for enammeling such, having none Artificiall. ${ }^{6}$

Douglas recognizes that her address to Parliament demands certain conventional language patterns, such as a preface to the reader; if she is not going to "baulke" at the metaphoric "roade way" of prophecy, she might as well not "baulke" at including the prefatory material conventional for a published work. However, she also claims a space of singularity for herself by refusing to praise or "complement" the reader or addresse of her text. The rejection of what she sees as the purely decorative "coulours" of rhetoric allows her to claim an unmediated prophetic stance simply by right of her unpolished language.

The preface concludes by declaring the body of the text to be of perhaps even worse quality, but also declares it to be immeasurably better for being so:

And this thing now, who knowes not too well; tedious to touch and fowle: but Blaines and Running-Soares nothing else all over, from the Elbow unto the feete: so this annoynting commended to all, for the blessed Readers and Hearers both. ..?

The merit of the Appeale is in its "Running-Soares," its textual imperfections, because the liquid from these sores enables the ritual baptism and "annoynting" of the pamphlet's readers. The artistic inadequacy of the text, paradoxically, confirms the author's call to prophecy. Douglas clearly took pains to conceal her meaning within scarcely accessible prose. Contrary to the established critical belief, Douglas's tortuous prose signifies not errors introduced by madness or illiteracy, but a structural symbolism deriving from the linguistically complicating role of the prophet. 
Problematically, since Douglas considered herself to be typologically related to the Old Testament prophet Daniel, Douglas's intricately destabilized rhetoric is at odds with Daniel's role as the elucidator of dreams and visions. His first task under Nebuchadnezzar, for example, is to describe the king's dream, without the king having told anyone of its details, and to interpret it to him; Daniel finds renown when the king confirms his description and accepts his exegesis. Daniel's own visions are more complicated than his elucidations, in that they sometimes include Gabriel as an internal interpreter and exegete, but even then they are finally interpreted within the book of Daniel, and not left to later persons to puzzle over and draw out. This tension between Daniel's calling as an interpreting prophet and Douglas's as a problematizing one is not to be easily resolved, and finds no real expression in her own writings.

Theodore Spencer answers this sort of problem by relying on an idea that Douglas lived in a "state of emotional and mental disequilibrium." Spencer's argument reveals its prejudices, however, by finding proof in her remarrying three months after the death of her first husband; Spencer recognizes this a symptom of mental instability, but his diagnosis may say more about Spencer than about Douglas to post-psychoanalytic criticism. Spencer goes on to call her "a wild-eyed and ominous Cassandra" and "mad, violent, and proud, obsessed by religious delusions, ... [and] furiously anxious to justify herself in print," claiming that her prose style relates directly to her mental condition. ${ }^{8}$

On the other hand, Esther Cope's portrait of Lady Eleanor as a perpetual irritant to the king, although attempting to correct Spencer's view, depends on a similar argument. Cope proposes that "questioning her mental stability offered [the king] a solution that avoided difficult issues," but concludes by asserting that over "the course of time, the scars of battle made her less and less willing to trust people of this world; persuaded that no one would listen, she cried louder and louder." Cope, although refusing Spencer's quasi-clinical definition of Douglas as mad by proposing that the king might have had her confined for purely political reasons, introduces the possibility that she was induced by circumstance to abandon reasonable language.

However, Cope's model as an increasingly erratic pattern of language use does not hold up. The 1625 A Warning to the Dragon, very long for Douglas at over 100 pages, is much clearer than a great deal of her later work, but the 1649 pamphlets The Crying Charge and Sions Lamentation are if anything just as clear as A Warning to the Dragon. As Megan Matchinske argues, "Calling on a single and convenient blanket statement to explain away the complexities of Davies's style necessarily neglects the myriad influences directing her 
composing processes." ${ }^{10}$ Defining Douglas as mad, although attractive to someone attempting to limit her subversiveness, is untenable, because it is based only in a single incarceration in Bedlam and in rhetorical patterns that can be explained as the product of several other causes.

Douglas's education has been claimed as another cause of this problematic complexity. Esther Cope, for example, describes her pamphlets as virtually illiterate: "Lacking in clear exposition, without classical or historical references, and, beyond an announcement that judgment would come in nineteen and one half years, having no chronology, they illustrate the educational limitations experienced by those of her sex." ${ }^{11}$ Cope's verdict, although (dubiously) more sympathetic than Spencer's judgement of insanity, allows Douglas even less room in which to operate as a free agent; at least madness would permit her a socially unstable subject position. It is important to recognize, contrary to Cope's expectations of a Renaissance woman writer, that Douglas's writing does not lack "clear exposition" because she cannot achieve it, but because she prefers it that way. In The Mystery of General Redemption, Douglas includes several Latin citations (Megan Matchinske goes so far as to compliment Douglas on "her obvious understanding of Latin"12), and claims enough Greek and Hebrew ${ }^{13}$ to recognize a pronounced misunderstanding of Old and New Testament conceptions of time in English translations of the Bible. This pamphlet reveals Douglas to have enjoyed considerable intellectual power, arguing through in exhaustive detail the different meanings available to the Hebrew word "sheol," translated variously into English as "grave," "hell," and "death," and to the Hebrew word meaning "for ages" and "for ever." From Douglas's perspective, the translation choices around these two terms reveal the translator's interest in supporting established church doctrine rather than in divining the actual words of the Scriptures. She refers to over a dozen Biblical texts in search of inaccurate translations of "Sheol" alone. Even if Douglas's argument is not definitive, it is at least clear and based in historically verifiable details. This pamphlet can be ignored only by refusing Douglas's interpretation of the details she traces, not by questioning the details provided her by her education.

Especially early in her career, Douglas's fascination with anagrams contributed greatly to her linguistic complexity. In A Warning to the Dragon, her first known published work, Douglas signes the title page "A SNARE O DEUIL ," the preface "O A SURE DANIEL" (both from Eleanor Davis or Eleanor Davies), and the text "Reveale O Daniel"; 14 even Daniel becomes the apocalyptic "I END AL." ${ }^{15}$ As A Warning to the Dragon develops, Douglas argues Daniel 8 into 
conformity with her attack on Catholicism by translating "Medes and Persians" (which Gabriel and Daniel 8:20 explains play the joint referent of the ram killed by the goat) as "SEND MEE SPANIARDS" (Spain being a traditionally Catholic nation) and the "rough goate" as "The Gothe Roague," 16 probably a reference to continental Protestantism. Charles I, the Stuart king she still hopes at this early stage of her career to influence, becomes "Al TRUTHS Cesar." 17 However, Douglas could not claim the absolute discursive power required to codify her interpretive anagrams as unvarying signifiers. Although in 1625 she uses anagrams fearlessly, her later work shows a marked decline in their use. In 1633, when Douglas appeared before the High Commission on charges of illegal printing and publishing, Sir John Lambe (a member of the commission) interpreted the name "Dame Eleanor Davies" as "NEVER SOE MAD A LADIE."18 Clearly, interpretive pressures, although elicited and welcomed by Douglas, cannot be controlled by her. Her need for Matchinske's "observant readers" provokes resistant readings from those not disposed to unravel her prose such as Lambe, Archbishop Laud, and Charles I, but also the readers throughout the past three centuries who have portrayed her as a more or less illiterate woman.

I have already mentioned Douglas's own anagrammatic self-revelation as Daniel, but her use of anagrams is not limited to herself, as $A$ Warning to the Dragon shows. On the title page of her 1633 broadside Woe to the House (which attacks Anne Stanley, her sister-in-law, for initiating the trial of Douglas's brother Mervyn for sodomy and rape), she recreates Elizabeth Stanley (Stanley's daughter from an earlier marriage) as "THAT IEZEBEL SLAIN" and Anne (Ana) Stanley as "A Lye Satann" (Hindle 79, no. 3). ${ }^{19}$ Although Douglas's 1643 Amend, Amend; God's Kingdome Is At Hand emphasizes anagrams, her own title of Daniel is one of the few to recur in works published after her repeated imprisonments of the 1630s, possibly because the fluid form of the anagram paradoxically requires absolute linguistic stability in spite of its seeming to destabilize language. Anagrams depend on a concept of language that can be shared as a bridge between the creator and the reader of an anagram; they depend upon two or more people sharing an identical conception of linguistic usage and convention. The solid state of this concept reifies language, rather than destabilizing it. Translation questions the legitimacy of anagrams as prophetic tools (is there an Italian equivalent to "Reveale O Daniel" that can be made from the same letters?), but the greatest difficulty is imposed by the problem of alternate or resistant readership. If "Reveale $\mathrm{O}$ Daniel" can become "Never soe mad a ladie," then "Al truths Cesar" can 
become "A ruthless cast" or "Rush castle rat." ${ }^{20}$ Her earlier reliance on anagrams attempted to reveal the fluidity of language; Douglas has no interest in codifying it.

Later in her career, she uses anagrammatic techniques for slightly different purposes. In describing the death of her grandson Henry Hastings, she speaks of his "hastning" unto heaven, ${ }^{21}$ which although not a true anagram of his last name is more indicative of her later linguistic freedoms. At the conclusion of The Restitution of Prophecy, Douglas assigns symbolic values to alphabetic characters to equate herself with Christ: "Subscribed I am $A$ \& $O . " 22$ This reference to Revelations 22:13 (which sanctifies her pamphlet by equating its ending with the end of the Bible) involves an additional reference to her signature on the pamphlet: "Ele: Da. \& Do."23 The "a" of Davies and the "o" of Douglas allow her symbolically to occupy the privileged space that Christ occupies. This alphabetic symbolism is brought to bear more anagrammatically on the Greek "chasma" to break it down as "Cha: \& Ma:, what a distance between them"; Douglas slights Charles I ("Cha:") by way of praising the Virgin Mary ("Ma:"). The confining female paradigm of Mary and Eve (heavenly virtue and earthly sin) becomes a relation between Mary and Charles, separating the question of sin from the question of gender. This search through language for buried meaning is an anagram in reverse rather than an anagram, more interested in the desedimentation of language than in its consolidation.

Douglas's attraction to anagram illustrates her interpretive approach to both the Bible and the world. The multiple levels of interpretation bound up in Douglas's language tend inevitably toward privileging the seventeenth century; her Biblical commentary and allusive references work to enhance her prophetic stance, not the other way around. The typological relation between the Old and New Testaments becomes a two-stage typology, in which seventeenth-century Europe operates as the third term:

The Cities Bridge on Arches, this Map as displayed Person, and place, Circumstances none more necessary: And some Haven Town from whence derives her Title of Honor. So from the Title great infers a Grand-mother. Then that imperious Hell-hound, more Mother Jezebels then one. ${ }^{25}$

This passage derives from Revelation 17, where established English tradition has made "BABYLON THE GREAT" (Revelations 17:5) a type of the fallen London, but Douglas's relation (typically) is more complicated than that. The whore that in Revelation represents Babylon also represents Jezebel, who Douglas 
also claims as a matter of course to represent Anne Stanley, the second wife of her executed brother Mervyn. The sequence of Jezebel $\rightarrow$ "great prostitute" (Revelations 17:1) $\rightarrow$ Anne Stanley intersects that of "great prostitute" $\rightarrow$ Babylon $\rightarrow$ London to such an extent that the map of London becomes a "displayed Person" - that of Anne Stanley. Stanley's "Title of Honor" (Lady Castlehaven) does indeed derive from "some Haven Town," but not the "Haven above" at which Lord Castlehaven arrives after his execution. ${ }^{26}$ The reference to "the Title great," although unclear, probably points to the Revelation phrase "the great prostitute," additionally denigrating Anne Stanley by implying that she would misread the Latin for "great prostitute" as "Grand-mother." Douglas's persistent focus on the need for her readers to interpret her texts correctly makes Anne Stanley's projected mistranslation a crime of considerable magnitude.

By 1651, the date of The Restitution of Prophecy, Douglas was in prison again, signing her pamphlet from the Fleet Prison. Her preface to this work illustrates her deeply felt need to claim authoritative utterance, calling her text "This Babe, . . in these plain Swathe-bands, . . No spurious off-spring of Davids, but the Son of peace." 27 The construction of the text as Christ, itself striking, is followed by Douglas's explicit claim of Mary's place as a prophet herself: "Sirs, to be plain, as in the first place, His Commission. He first of the new Prophet; so his and hers both: She the last of the old." ${ }^{28}$ More traditional associations to link the Bethlehem stable and the London prison follow to establish a relationship between Mary and Eleanor Douglas, but the notion of Mary's delivery of the Christ-child as the concluding act of pre-Christian prophecy, as a physical bringing-forth of the last religious signification prior to the age of Christ, inserts Douglas into far more radical territory.

In her description of the Fleet and of the production of her manuscript, Douglas slides between reading the Bible in terms of the present, and the present in terms of the Bible. After describing the streets outside the prison, Douglas separates them from

the true Narrow way (by suffering) that leads to life: From him a proper passage or mention. Straits of the Virgins-Womb had passed; besides Seafaring-persons his followers in that way not unexperienced, afore arrive the welcome Haven.

And so far Reader, for these excluded their Approbation, where parallel'd the Broad-way, Ebrieties leading to destruction. ${ }^{29}$

The metaphorization of Mary's birth canal as a narrow strait, through which Christ, ship-like, might pass, also refers to the safe passage of Douglas's 
manuscript through the narrow streets around the Fleet Prison. Douglas's typological reading of "the Virgins-Womb" as "the true Narrow way" that Christ tells Christians to follow (Matthew 7:13-14) is complicated by the fact that birth is a passage into earthly existence, a far cry from the heavenly bliss at the end of the narrow way. In addition, the exegetical Mystery of General Redemption uses the phrase "strait passages" to refer to particularly intractable passages from the Bible that she is working to elucidate. ${ }^{30}$ The multitudinous references in this passage are even further complicated by the words "Haven" and "Broad-way."

Recurring again in The Restitution of Prophecy as "some Haven Town" by which Anne Stanley receives her title and "the Haven above" at which Douglas's brother arrives after his execution, ${ }^{31}$ the word "Haven" in the above quotation radically destabilizes the sentence by its inclusion. It suddenly becomes possible to read this sentence not just as a statement that birth is necessary before death and redemption can occur, but as an attack on Anne Stanley for charging her husband ("the welcome Haven") with rape when "Seafaring-persons" (their male Irish servants?) had themselves followed in "that way not unexperienced." Caroline Bingham quotes Lord Castlehaven from his trial as stating that Stanley "had had a child before which he concealed to save her honour," ${ }^{2}$ so it is a possibility that Douglas is obliquely referring to Stanley's vagina as "that way not unexperienced" in direct contrast to Mary's virginity. (The comment in The Restitution of Prophecy that Stanley is "more mother Jezebels then one," 33 when combined with the anagram of "ThAt Iesebel SLAIN" from Woe to the House, ${ }^{34}$ may also refer to this earlier child.) The phrase "Broad-way" refers not only to Christ's distinction in Matthew 7:13-14 between the narrow road to life and the broad road to destruction, but to Giles Broadway, the servant who testified that Lord Castlehaven had helped him rape Anne Stanley, and even possibly to Stanley's vaginal "way not unexperienced." However, before further expansion of this kaleidoscopic sequence of allusions, Douglas cuts herself off as "unwilling to transgress the bounds of a Preface," 35 and moves on to her text.

Douglas's strategy throughout The Restitution of Prophecy mirrors that which she finds in the Bible, namely "The secrets of the Gospel under Allegories covered and Parables, precious Leaven, generality or scope whereof reflects." 36 Reading the Bible is an interpretive renovation of "Allegories covered and Parables" by means of accurately grasping the appropriate "generality or scope whereof" to "reflect" upon them. She does not occupy the place of reader, though, but of Biblical writer; she is not Daniel the exegete, but 
the dreaming Daniel whose visions must be interpreted by her own private Gabriel, her reader. However, she uses Biblical commentary to set up a loose interpretive framework that gradually becomes implicated in her seventeenthcentury vehicle.$^{37}$ Her discussion of the book of Daniel is thoroughly linked to her understanding of her own place in the world:

Whereupon like his killing and flaying Decree, Dan. 2 etc. She to appear and answer forthwith, as by that Babylonian reference annext, Signed Sydney, Mountagne, for presuming to prefer and imprint, That detestable, \&c An. Dom. 1633. October, Whitehals no petty Trespass. ${ }^{38}$

While commenting on Daniel's elucidation of a dream that Nebuchadnezzar refuses to describe but demands to have interpreted for him (or else all his wise men shall be put to death by his "killing and flying Decree"), Douglas quotes from a 1633 letter addressed to her that she reprinted in her 1649 The Blasphemous Charge Against Her. In the earlier text, this letter appeared in the context of a daring address to the king: "Ask me foregiveness, if so be you expect to finde Mercy in this world or the other." ${ }^{39}$ In The Restitution of Prophecy, after his death, Charles explicitly becomes Nebuchadnezzar to Douglas's Daniel; this is not an allegorical or metaphorical reference, but a relocation of Daniel's voice (as her own) into seventeenth-century political discourse.

Similarly, Douglas's references to Archbishop Laud become an interpretive house of mirrors, reflecting and refracting both testaments through her seventeenth-century lens:

He the last Arch. B. of Canterbury. The one Talent even buried by his hand, Achans graceless scholar.

In the Earth, he buried in the Valley of Achor: a heap of Stones Dunghillike; his Monument and theirs consenting thereto: Had not alone troubled Joshua, expotulating in rent clothes: Wherefore, etc.

Root of all Evil, filthy lucre confesses did covet: Thus and thus, etc. In the Valley of Trouble, took up his Lodging. Sign of the Spade, fitter for it. ${ }^{40}$

The relatively straightforward reference to Laud's burying his "one Talent" (Christ's parable of the talents in Matthew 25:14-30) develops into a reference to Joshua 7, which tells the story of "Achan," a man who stole some of the "devoted things" (Joshua 7:1) and buried them beneath his tent in the Valley of Achor. The Lord tells Joshua that someone has stolen these things; Achan confesses, and is stoned to death and buried beneath a pile of stones in the Valley of Achor (Joshua 7:25-26). (The burial within the "Dunghil" probably 
refers to Lichfield Church, which buried some of its relics and ornamentation in a dunghill, according to Douglas, to save them from destruction by a parliamentary army. ${ }^{41}$ ) Achor is the Hebrew word for "trouble," so the "Valley of trouble" Douglas refers to in the next paragraph is the same place where Achan (i.e., Laud) "took up his Lodging [at the] Sign of the Spade" (i.e. in the grave) for his sins. His sin is specifically his desire for "filthy lucre," which refers to 1 Timothy 6:10 and Deuteronomy 7:25, the most explicit injunctions against avarice. Eventually, as this discussion progresses, the attack on avarice becomes one on usury, and then on "Tythe gatherers." 42

After stating that her opening discussion of Matthew 25 will proceed into a disposition on the parable of the talents, and before the reference to Laud that mentions this parable, Douglas enters into detailing the charges against and trial of her brother. After a brief attack on "Anne Strange" (who can only be Anne Stanley), Douglas introduces several Biblical references:

As shews in the day of his wrath, wounding even Kings etc. Sit thou on my right, etc. thy Sentence (as much to say) until upon them be accomplished (Revel. 13) Even the brutish Beast wounded in the head, his mortal wound: And Hers (Rev. 17) where one of the seven Angels which had the seven vials (namely the last of them) saying, Come, I will shew thee the Judgement of the great Whore or great bellied Harlot fitting on many waters. ${ }^{43}$

This passage includes almost innumerable references, the clearest being to Psalm 110:5, Matthew 20:21 and 22:44, Mark 12:36, Luke 20:42, Acts 2:34, Hebrews $1: 13$, and Revelation $! 3: 3$ and $17: 1 .{ }^{44}$ An overly concise paraphrase of this passage might read, "God's wrath will be visited in the end upon Anne Stanley and the other people responsible for the execution of Lord Castlehaven," but this ignores the complex interplay between the citations. Douglas relates the wrath of God in making David's "enemies a footstool for [David's] feet" (Psalm 110:1), to God's plan for who shall sit at Christ's right hand in Heaven, to his invitation to David that he be the one to sit at His right hand, to the final judgement against the world. Lord Castlehaven's execution by beheading seems to place him as the beast of Revelation 13 who receives the "mortal wound" in the head - strangely, given the beast's blasphemies and Douglas's conception of her brother as wrongly accused. The wound itself seems more appropriate for "the great Whore or great bellied Harlot." Lord Castlehaven, in Douglas's mythology, should be more akin to David than to the beast; this may be an instance of deliberate referential instability that Douglas uses as a test of her readers. Megan Matchinske views Douglas's rhetoric as an inten- 
tional enigma that "demand[s] a tremendous personal response; individual readers must authorize her work through their interpretations of it." ${ }^{45}$ If this is correct then her rhetorical density is a way of sorting her readers into wheat and chaff (so to speak). Douglas here attempts to justify her prophetic role by forbidding her reader any direct knowledge of her personally mythological structure. The uncertainty of Lord Castlehaven's typological double is one extreme instance of this instability, but others can be found throughout her writing. In particular, Douglas's frequent use of etc. leaves her reader to interpret her writings without guidance from her, but also paradoxically forces the reader into specific interpretive gestures, such as tracing her references and not just accepting the fragment she provides.

Douglas's title pages almost always include Biblical citations, many of which end with etc. The cover page of The Lady Eleanor, Her Appeale to the High Court of Parliament, for example, includes two citations, both ending with etc. The second, "See thou tell no man, but goe thy way, shew, etc." (Matthew 8:4), uses the abbreviation primarily as an ellipsis to avoid quoting the rest of Christ's short speech to the healed leper that he should go to the temple and "shew" himself to the priests. However, the first citation, "Behold, even as the eyes of Servants looke to the hand of their Masters, etc." (Psalm 123:1-2), omits the (for Douglas) crucial point to the psalm. An appeal for mercy, this psalm ends by describing the appellant's situation:

Have mercy on us, O LORD, have mercy on us, for we have endured much contempt.

We have endured much ridicule from the proud, much contempt from the arrogant (Psalm 123-3-4).

Although Douglas appears to describe her relation with Parliament as a servant's submission before a master, she quotes this psalm instead to guarantee covertly the perception of her that she desires: to equate herself with those servants of the Lord wrongly oppressed by "the proud" and "the arrogant." Since prudence (or humility, however rarely Douglas approaches the humility topos as such) dictates that she not so openly state her claim to a hearing before Parliament (which has always been in large measure made up of both "the proud" and "the arrogant"), Douglas instead cites that part of the psalm that looks like flattery. As in her use of etc. to obscure the workings of her brother's trial, Douglas uses it here as a cover to allow the more heavily charged section of the psalm to enter into public discourse attached to her name. 
The Lady Eleanor, Her Appeale opens with a quotation from Daniel 2:34, which Douglas subsequently discusses: "Thou sawest till that a Stone was cut out without hands, which smote the Image upon the feete: That of Iron, and Clay, and brake them in peeces, etc. ${ }^{.46} \mathrm{Etc}$. is used straightforwardly again as an ellipsis, standing in for further text that Douglas feels it unnecessary to quote. This passage is part of Daniel's description of Nebuchadnezzar's dream (see pages 12-13 above), which Daniel goes on to explain as God's destruction of the empires that follow Nebuchadnezzar's. The exegesis has already been performed by Daniel, but Douglas takes it upon herself to obscure his exegesis in her $e t c$. and to perform her own:

Heere these touching the Iron-age, remaines of time, a tast thereof; the Sonnes of the Prophets for their use, needlesse; as into the water to cast a Logg, wherein a sticke cut downe, but thrown sufficeth, or to give a touch, etc. As farre either from building upon others foundation, theirs etc. The lanthorne unusefull, when the Moone giving light at full, not trespassing in that way here, nor borrowing either etc. And so farther of the latter dayes, these even being become drosse changed, even commanded these by him. ${ }^{47}$

Douglas's use of three etc.'s implies that a great deal has been left out of her prose, which her elliptical syntax confirms. The first part of this quotation (up to the first semi-colon) might be paraphrased as, "Here is a taste of the remains of time, before the Iron age," a taste that is "needlesse" for the "Sonnes of the Prophets." This prophetic exegesis is "needlesse" for those able to read and understand it; her writing is an excess comparable to throwing a "Logg" rather than a "sticke," to using a "lanthorne" during a full moon. However, Douglas proposes to speak "farther of these latter dayes" anyway, and proceeds to do so.

In the above quotation, Douglas's language is heavily freighted with Biblical allusions. The casting of the wood recalls 2 Kings 6:1-6, where Elisha and the other prophets are cutting trees on the banks of the Jordan. An iron axhead falls into the water, so the prophet who dropped it laments that he had borrowed it; Elisha then cuts a stick and throws it into the water, making the axhead float up to the surface. Douglas's words "Iron," "logg," "a sticke cut downe, or thrown," and "borrowing" all recur at 2 Kings 6:1-6; her reference to "foundation" might also derive from there, because the prophets are cutting trees in order to build themselves a larger meeting-place. However, "foundation" more likely refers to Romans 15:20 (where Paul comments," It has always been my ambition to preach the Gospel where Christ was not known, so that I would not be building on someone else's foundation") or to 1 
Corinthians 3:10-11 (Paul's statement that "no one can lay any foundation other than the one already laid, which is Jesus Christ"). The prophetic tenor of both of these, especially as they occur within Paul's educational epistles, would suit Douglas nicely.

Further allusions can also be teased out of this passage. Several, for example, can be traced to Isaiah 60, Isaiah's vision of the glory of Zion. The light of the Lord in this apocalyptic vision will blot out that of the sun and the moon (60:19), just as Douglas's moon blots out her "lanthorne"; God promises to exchange Zion's "iron" for silver, and stones for "iron" (60:17). Similarly, the word "borrowing" may refer to Jeremiah 15:10, where Jeremiah laments "I have neither lent nor borrowed, yet everyone curses me." Of course, the epigraph to The Lady Eleanor, Her Appeale implies ill treatment, but this otherwise tenuous reference is strengthened by God's question at Jeremiah 15:12, "Can a man break iron - iron from the north - or bronze?"; the end of the iron age is after all figured in Daniel as the shattering of the iron feet of a statue. Finally, Douglas's "drosse" may refer to Proverbs 25:4-5 ("Remove the dross from the silver, and out comes material for the silversmith; remove the wicked from the king's presence, and his throne will be established through righteousness"), but more probably to Ezekiel 22:17-22, where God tells Ezekiel that "the house of Israel has become dross," and that he will therefore "gather [them] into Jerusalem and melt" them. Again, references to iron are embedded within the passage of Ezekiel dealing with the "latter dayes" of Israel. ${ }^{48}$

The interpretive pressure that must be exerted upon, the referential scope that must be permitted to, Eleanor Douglas's texts are immense. Her reliance on etc. and other diffusing rhetorical techniques authorizes her reader to fill up, to occupy the interstitial interpretive gaps she creates in her texts. In Douglas's own handwritten marginal annotations on her published pamphlets (as Matchinske notes), Douglas "continually refers to issues of clarity, insisting that if anything she is too plain in her texts." ${ }^{49}$ Douglas has no interest in creating clarity, because if her reader possesses the necessary knowledge and interpretive skill to address her writings, then clarity will exist in the reading and be retrospectively (if privately) imposed upon the text itself. As Matchinske remarks, "without considerable background and unlimited patience, it is difficult to follow her texts, much less understand them." ${ }^{.50}$ It is not enough simply to be an "observant reader," in Matchinske's formulation of Douglas's intended readership, because observing the text will only allow the reader to recognize Douglas's rhetorical complexity, not to unravel it. 
Easy reading of these pamphlets demands Biblical expertise far beyond my own. Douglas's texts are worth the effort of interpretation, certainly, but it is unlikely that her contemporarues would have been inclined to exert the necessary interpretive pressure. Matchinske argues that Douglas's writing "is sabotaged both by the frustrations that Davies faces as a writer" and by the inapplicability to her writings of Puritan "holy hatred," the only rhetorically accepted prophetic stance available to her, ${ }^{51}$ but the sabotage may also have been done by Douglas's conscious refusal of structural paradigms. Daniel, her basic model, is an elucidating prophet; Eleanor Douglas eschews elucidation, for the most part, in favour of problematizing her subjects. Her fundamentally insurrectionary rhetoric refuses easy interpretation, refuses direct interpretation altogether, and the crucial subjects of her pamphlets were wrongly obscured by her readers in a hasty and only superficially valid literary judgement of Douglas as confined to illiteracy and madness.

\section{University of Alberta}

\section{Notes}

My thanks to Patricia Demers for introducing me to Eleanor Douglas, to my wife Nancy Pekter for her always valuable comments, and to Kent Lewis for his insightful reading of both Douglas's pamphlets and this essay. A modern edition of Lady Eleanor Douglas's works has appeared recently, Esther S. Cope's Prophetic Writings of Lady Eleanor Davies (New York: Oxford University Press, 1995), but I have worked from the seventeenthcentury versions of her texts.

1. Megan Matchinske, "Holy Hatred: Formations of the Gendered Subject in English Apocalyptic Writing, 1625-1651," English Literary History, 60 (1993), p. 369. Matchinske refers to her as "Davies," Esther Cope and Theodore Spencer as "Lady Eleanor," and Caroline Bingham as "Davis"; I have chosen to go with "Douglas" because it was as "Eleanor Douglas" that she published her prophetic writings.

2. Esther S. Cope, “'Dame Eleanor Davies Never Soe Mad A Ladie'?,” Huntington Library Quarterly, 50 (1987), p. 135.

3. Theodore Spencer, "The History of an Unfortunate Lady," Harvard Studies and Notes in Philology and Literature, 20 (1938), p. 48. For additional biographical information, see Esther Cope's biography of Eleanor Douglas, Handmaid of the Holy Spirit (Ann Arbor: University of Michigan Press, 1992).

4. However, I haven't found any significantly postmodern criticism of Douglas, apart from Megan Matchinske's work on the gendered Renaissance subject. Lynette McGrath has published an Irigarayan reading of Aemilia Lanyer's poetry, but Douglas has so far found no takers; a Kristevan reading of Douglas's rhetoric as antimasculinist and as unsettling canonical linguistic encoding would be fascinating, although beyond the scope of this paper. 
See also Teresa Feroli's "The Sexual Politics of Mourning in the Prophecies of Eleanor Davies," Criticism, 36 (1994): 359-382.

5. Matchinske, p. 367. All references to the Bible within my text (not Douglas's) are from the New International Version. References were traced primarily through Nelson's Complete Concordance of the Revised Standard Version Bible (1957).

6. Eleanor Douglas, The Lady Eleanor, Her Appeale to the High Court of Parliament ([London], 1641), p. 5. For further information on women's petitions to Parliament of this period, see Ellen McArthur, "Women Petitioners and the Long Parliament," English Historical Review, 24 (1909): 698-709; and Patricia Higgins, "The Reactions of Women," in Brian Manning, ed. Politics, Religion, and the English Civil War (London: E. Arnold, 1973): 178-222.

7. The Lady Eleanor, Her Appeale, p. 6.

8. Spencer, pp. 46, 49, 59.

9. Cope, art. cit., pp. 137, 139.

10. Matchinske, p. 366.

11. Cope, art. cit., p. 135.

12. Matchinske, p. 367.

13. Eleanor Douglas, The Mystery of General Redemption ([London], 1647), pp. 11-12.

14. Eleanor Douglas, $A$ Warning to the Dragon and All His Angels (n. p., 1625), [a1'], [a2"], and 1.

15. A Warning to the Dragon, [a $\left.2^{\mathrm{v}}\right]$.

16. Ibid., p. 38.

17. Ibid., p. 85 .

18. Cope, art. cit., p. 137.

19. I have not seen Woe to the House, because it has not yet been microfilmed; it appears as title 904.5 in A W. Pollard and G. R. Redgrave's A Short-title Catalogue of Books Printed in England, Scotland, and Ireland and of English Books Printed Abroad, 1475-1640, second edition, revised and enlarged (London: Bibliographical Society, 1986-), but does not appear in the cross-referenced list of works produced in the microfilm series Early English Books, 1475-1640. The reference to its title page comes from C. J. Hindle's detailed bibliography of Douglas's pamphlets. For information about Elizabeth Stanley's rape and abuse under the orders of Eleanor Douglas's brother, see Caroline Bingham's article, "Seventeenth-Century Attitudes Toward Deviant Sex," Journal of Interdisciplinary History, 1 (1971).

20. If these anagrams seem unconvincing refutations, that is because they are my own; I hoped only to help Sir John Lambe illustrate the instability of the anagram as a means of signification, not to achieve seventeenth-century virtuosity.

21. Eleanor Douglas, Sions Lamentation, Lord Henry Hastings, His Funeral Blessing by His Grandmother, the Lady Eleanor ([London?], 1649), p. 4. 
22. Eleanor Douglas, The Restitution of Prophecy (n. p., 1651; Exeter: The Rota-U of Exeter Press, 1978), pp. 51-52.

23. Ibid., p. 52.

24. Ibid., p. 25. The analysis of "chasma" occurs in a handwritten annotation on the outside margin of the page. Douglas does not identify herself as the writer, but she is known to have annotated her published work (Hindle, p. 74; Matchinske, p. 376), and the handwriting sample provided by Hindle (p. 87) matches that on the copy of The Mystery of General Redemption microfilmed as reel 1422, item 17 of Early English Books, 1641-1700 that I am working from.

25. Restitution of Prophecy, p. 10.

26. Ibid., p. 21. Castlehaven was executed for helping his footman rape Lady Castlehaven and for committing sodomy with several of his male servants; these were in fact only a few of the offences he could have been tried for. See Caroline Bingham, art. cit.

27. Restitution of Prophecy, [i].

28. Restitution of Prophecy, [ii].

29. Restitution of Prophecy, [iii].

30. Restitution of Prophecy, p. 21.

31. Restitution of Prophecy, pp. 10, 21; see page 12 above.

32. Bingham, p. 458.

33. Restitution of Prophecy, p. 10

34. See page 10 above.

35. Restitution of Prophecy, [iii].

36. Restitution of Prophecy, p. 1.

37. The term "vehicle" refers of course to the tenor and vehicle of a metaphor, but it is, I hope, clear that Douglas refuses this distinction, and continually metaphorizes one as the other, and vice versa. Metaphor is too stable a trope to use as a definition of Douglas's style, but is one of the closest to it.

38. Restitution of Prophecy, p. 28. The man named here as Sydney Mountagne is named in The Crying Charge as "Sydney Mountague."

39. Eleanor Douglas, The Blasphemous Charge Against Her ([London], 1649), p. 2.

40. Restitution of Prophecy, pp. 29-30.

41. Cope, art. cit., p. 136.

42. Restitution of Prophecy, p. 31.

43. Restitution of Prophecy, pp. 9-10.

44. The language of the psalm is explicitly echoed in the passages cited from Matthew, Mark, 
Luke, Acts, and Hebrews; the reference is unclear, except to mention sitting at the right hand. Each of these sources places the phrase in a slightly different context, but there is no way to determine which allusion is the definitive one. Douglas's usual rhetorical instability makes me suppose that she intended as broad a frame of reference as she could manage.

45. Matchinske, p. 368.

46. The Lady Eleanor, Her Appeal, p. 7.

47. Ibid., pp. 7-8.

48. Ibid., p. 8.

49. Matchinske, p. 367.

50. Id.

51. Matchinske, p. 371. 